Gut, 1966, 7, 578

\title{
Vitamin E levels after gastric surgery
}

\author{
P. J. LEONARD, M. S. LOSOWSKY, AND C. N. PULVERTAFT \\ From the Department of Medicine, The General Infirmary, Leeds, and \\ the York County Hospital
}

EDITORIAL SYNOPSIS Low plasma values for vitamin E are reported in patients who have had a Polya gastrectomy. The full significance of this finding is not yet fully established.

Evidence suggestive of vitamin E deficiency has bcen reported in children and adults with malabsorption (Gordon, Nitowsky, Tildon and Levin, 1958; Braunstein, 1961 ; Binder, Herting, Hurst, Finch and Spiro, 1965). In addition to low plasma tocopherol levels, experimental depletion of vitamin $\mathrm{E}$ in animals and man results in an increased haemolysis of erythrocytes exposed to hydrogen peroxide (Rose and György, 1952; Horwitt, 1962), and this is widely used as an additional test for deficiency of the vitamin.

After partial gastrectomy and other operations for peptic ulcer, malabsorption may be found (Everson, 1952; Shingleton, Isley, Floyd, Sanders, Baylin, Postlethwait, Ruffin, 1957; Tyor and Ruffin, 1958; Weir and Gatenby, 1963; Deller and Witts, 1962), and it seemed possible that vitamin E deficiency might also occur.

In this study the plasma vitamin $\mathrm{E}$ levels and the susceptibility of erythrocytes to haemolysis by hydrogen peroxide were measured in patients after gastric surgery, and compared with values found in normal subjects and patients with peptic ulcer.

\section{PATIENTS STUDIED AND METHODS}

Twenty-six patients who had had a Polya gastrectomy and attended hospital with complications attributed to the operation and 110 patients who had had various gastric operations (Polya gastrectomy in 55, vagotomy and gastroenterostomy in 18, vagotomy and antrectomy in 16 , vagotomy and pyloroplasty in 13 , and Billroth I gastrectomy in eight) and were attending the routine gastric follow-up clinic at the York County Hospital (Visick, 1948) were studied. Seventeen subjects without known disease and 28 patients with a peptic ulcer who had not had surgery acted as controls.

Plasma vitamin E levels were measured as described by Martinek (1964). The hydrogen peroxide haemolysis test was carried out on fresh erythrocytes as described by
Rose and György (1952), glucose being added to the incubating medium as suggested by Horwitt (1962).

Mean plasma vitamin $\mathrm{E}$ levels in normal subjects vary from one study to another (Gordon et al., 1958; Binder et al., 1965; Bieri and Prival, 1965), but it is generally agreed that normal subjects usually have values above $0.5 \mathrm{mg} . / 100 \mathrm{ml}$. (Goldbloom, 1960; Leitner, Moore, and Sharman, 1950). A plasma vitamin E level of $0.45 \mathrm{mg} . / 100 \mathrm{ml}$. has been arbitrarily chosen as the lower limit of normal in the present study. One normal subject had a low plasma level.

\section{RESULTS}

In the 17 normal subjects the mean plasma vitamin $\mathrm{E}$ level was $0.74 \mathrm{mg} . / 100 \mathrm{ml}$. ( $\pm \cdot 05$ S.E.). The mean level in the 28 ulcer subjects was $0.63 \mathrm{mg} . / 100 \mathrm{ml}$. $( \pm 0.03$ S.E. $)$ which is significantly lower $(p<0.05)$ than in the normal subjects. Mean levels of $0.34 \mathrm{mg}$./ $100 \mathrm{ml} .( \pm 0.03$ S.E. $)$ and $0.37 \mathrm{mg} . / 100 \mathrm{ml} .( \pm 0.02$ S.E.) were found in the hospital and clinic groups of Polya gastrectomy patients respectively (Fig. 1). These results are not significantly different from each other but are significantly lower $(p<0.001)$ in both instances, than the value found in the ulcer groups.

The haemolysis test was abnormal $(>4 \%)$ in none of the normal subjects, in three $(11 \%)$ of the ulcer group, in $12(48 \%)$ of the hospital gastrectomy group, and in $28(53 \%)$ of the gastrectomy group from the follow-up clinic. Abnormal haemolysis was seen in only six $(13 \%)$ of those who had other operations.

Due to the relatively small number of patients the effect of the time interval after surgery cannot be studied in detail, thus subjects were simply divided according to whether the operation had been performed more than 10 years previously or less. The results are presented in Figure 2. The mean plasma vitamin $E$ level did not vary significantly from one 


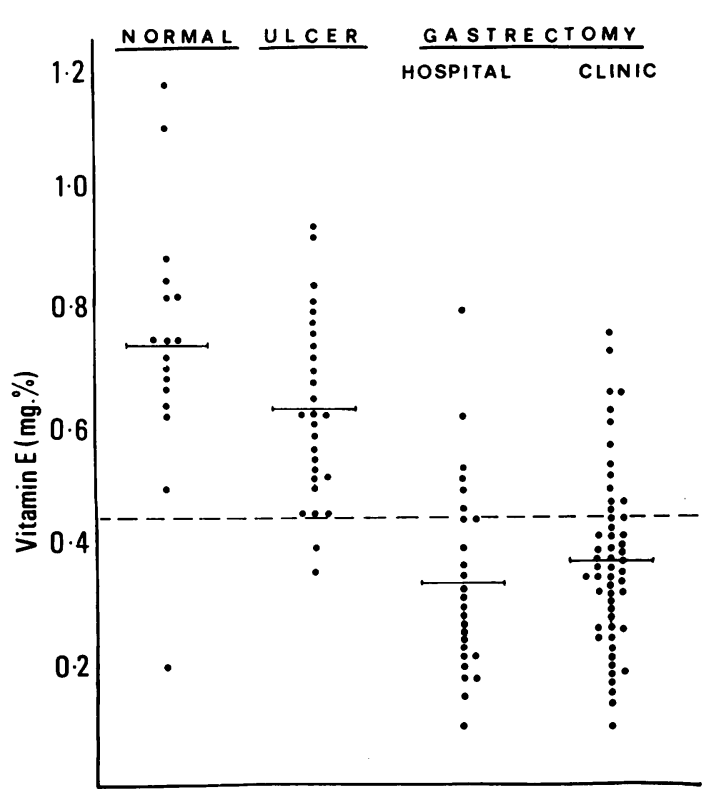

FIG. 1. Plasma vitamin E levels in (L. to R.) normal subjects, patients with peptic ulcer, 'hospital' gastrectomy patients, and 'clinic' gastrectomy patients. Mean value in ulcer group significantly lower than in normals $(p<0.05)$. Mean values in both gastrectomy groups significantly lower than ulcer group $(p<0.001)$.

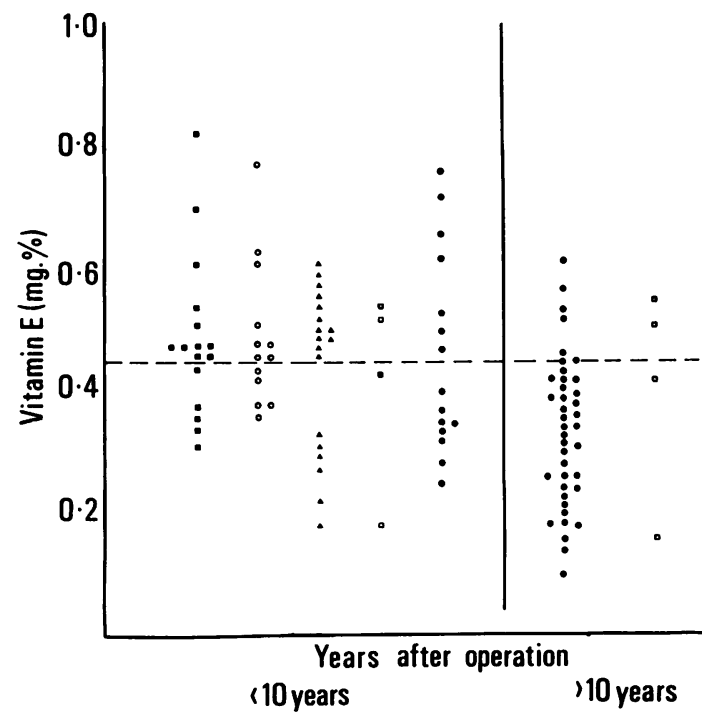

FIG. 2. The effect of length of time after gastric surgery on plasma vitamin E level. $=$ Polya gastrectomy, $\bigcirc=$ Billroth I gastrectomy, $\mathbf{\Delta}=$ vagotomy and gastroenterostomy, $\bigcirc=$ vagotomy and pyloroplasty, $\square=$ vagotomy and antrectomy. There was no significant difference between mean values in the under-10-year group. The mean level in over-10-year Polya gastrectomy group was signifcantly lower $(p<0.01)$ than in the under-10-year group. procedure to another in those who had an operation less than 10 years previously. In the 47 subjects who had a vagotomy and either a gastroenterostomy, pyloroplasty, or antrectomy the mean plasma level was $0.47 \mathrm{mg} . / 100 \mathrm{ml}$. ( \pm 0.02 S.E. $)$. This was significantly lower $(p<0.001)$ than the value found in the ulcer group and identical with that of the Polya gastrectomy subjects in the under-10-year group. The 40 Polya gastrectomy subjects in the over-10-year group had a mean plasma level of $0.33 \mathrm{mg} . / 100 \mathrm{ml}$. $( \pm 0.02$ S.E. $)$ which is significantly lower $(p<0.01)$ than the value in the under-10-year group. The incidence of low plasma vitamin $\mathrm{E}$ levels was $82 \%$ at 10 years or more after Polya gastrectomy, $83 \%$ at less than 10 years after Polya gastrectomy, and $33 \%$ in those with other operations less than 10 years previously.

\section{DISCUSSION}

Doubt exists as to the exact requirement and role of vitamin $E$ in man. There is a renewal of interest in these problems with the finding of low plasma levels in various diseases and the possible beneficial effect of vitamin $\mathrm{E}$ in certain conditions (Horwitt, 1962; Marks, 1962; Binder et al., 1965).

Our results show that low plasma levels of vitamin $\mathrm{E}$ are found following gastric surgery, occurring in as many as four out of five patients more than 10 years after a Polya gastrectomy. The incidence of low levels in those who have had an operation less than 10 years previously is about half of this value and is probably not greatly influenced by the type of operation performed. Low plasma vitamin $\mathrm{E}$ levels and positive haemolysis tests were somewhat less common after operations other than Polya gastrectomy, but $80 \%$ of these subjects had been operated on less than five years ago. Post-gastrectomy nutritional deficiencies usually appear after more than five years (Paulson and Harvey, 1954; Brit. med. J., 1960; Deller and Witts, 1962) and it seems likely that as the time interval after operation increases, the incidence of low plasma vitamin $\mathrm{E}$ levels and positive haemolysis tests will increase to the level found in the Polya gastrectomy group more than 10 years after operation. If malabsorption of vitamin $E$ is the cause of the low plasma levels, the finding of low levels after various gastric operations, other than gastrectomy, is not unexpected, since malabsorption of fat has been reported following most of these operative procedures (Fox and Grimson, 1950; Brain and Stammers, 1951; Everson, 1952; MacLean, Perry, Kelly, Mosser, Mannick, and Wangensteen, 1954).

Low plasma levels and positive haemolysis tests were apparently not related to the incidence of other complications of gastrectomy since the findings were 
almost identical in the group presenting because of complications and those attending the routine followup clinic in whom complications were rare.

Anaemia is a not infrequent complication of gastrectomy, and although usually responding to iron or vitamin $B_{12}$ (Paulson and Harvey, 1954; Deller and Witts, 1962; Weir and Gatenby, 1963), some patients are found who do not respond to any of these forms of treatment. Anaemia attributable to vitamin $\mathrm{E}$ deficiency has been documented in monkeys (Dinning and Day, 1957), and administration of the vitamin has been shown to correct some anaemias associated with malnutrition in man (Majaj, Dinning, Azzam, and Darby, 1963; Marvin and Audu, 1964; Sandstead, Gabr, Azzam, Shuky, Weiler El Din, Mokhtar, Prasad, El Hifney, and Darby, 1965). The significance of vitamin $E$ in postgastrectomy anaemias has not been evaluated.

Although a large proportion of subjects were found to have low plasma vitamin E levels following gastrectomy, it is not known if this is associated with any undesirable effects in the patient. In this context, the haemolysis test may be a better index of deficiency than the plasma level, since it reflects the resistance of erythrocytes to oxidation and an antioxidant effect is known to be a biological function of vitamin E; approximately half of all gastrectomy patients showed abnormal haemolysis in this test.

The mean plasma vitamin $\mathrm{E}$ level in the ulcer group was significantly lower than in the normals. This raises the question of whether the low values found after gastrectomy are really secondary to the operation, or whether a study of ulcer subjects in relation to the length of the history might show similar findings in those of long duration.

Further work is in progress to evaluate the significance of these findings.

We wish to thank Professor R. E. Tunbridge for his help and encouragement, The York Peptic Ulcer Research Trust for financial assistance, Mrs. R. Nicolson, Mrs. M. A. Pybus and Mrs. M. Dent for help in running the clinic and secretarial assistance, surgeons J. H. Conyers, R. A. Hall, J. K. Willson-Pepper and T. S. Matheson, and Dr. D. W. Miles for access to the patients, and Misses N. Gibson and B. Clarke for technical assistance.

\section{REFERENCE}

Bieri, J. C., and Prival, E. L. (1965). Serum vitamin E determined by thin-layer chromatography. Proc. Soc. exp. Biol. (N.Y.), 120, 554-557.
Binder, H. J., Herting, D. C., Hurst, V., Finch, S. C., and Spiro, H. M. (1965). Tocopherol deficiency in man. New Engl. J. Med., 273, 1289-1297.

Brain, R. H. F., and Stammers, F. A. R. (1951). Sequelae of radical gastric resections: clinical and metabolic findings in 35 cases. Lancet, 1, 1137-114.

Braunstein, H. (1961). Tocopherol deficiency in adults with chronic pancreatitis. Gastroenterology, 40, 224-231.

British Medical Journal. (1960). Editorial. Vitamin $\mathbf{B}_{12}$ neuropathy after gastrectomy. Brit. med. J., 2, 1507-1508.

Deller, D. J., and Witts, L. J. (1962). Changes in the blood after partial gastrectomy with special reference to vitamin $\mathbf{B}_{12}$. I Serum vitamin $\mathbf{B}_{12}$, haemoglobin, serum iron and bone marrow. Quart. J. Med., 31, 71-88.

Dinning, J. S., and Day, P. L. (1957). Vitamin E deficiency in the monkey. I. Muscular dystrophy, hematologic changes, and the excretion of urinary nitrogenous constituents. J. exp. Med., 105, 395-402.

Everson, T. C. (1952). Collective review. Nutrition following total gastrectomy, with particular reference to fat and protein assimilation. Int. Abstr. Surg., 95, 209-230.

Fox, H. J., and Grimson, K. S. (1950). Defective fat absorption following vagotomy. J. Lab. clin. Med., 35, 362-365.

Goldbloom, R. B. (1960). Investigations of tocopherol deficiency in infancy and childhood. Studies of serum tocopherol levels and of erythrocyte survival. Canad. med. Ass. J., 82, 1114-1117.

Gordon, H. H., Nitowsky, H. M., Tildon, J. T., and Levin, S. (1958). Studies of tocopherol deficiency in infants and children. V. An interim summary. Pediatrics, 21, 673-681.

Horwitt, M. K. (1962). Interrelations between vitamin E and polyunsaturated fatty acids in adult men. Vitam. u. Horm., 20, 541558.

Leitner, Z. A., Moore, T., and Sharman, I. M. (1960). Vitamin A and vitamin $\mathrm{E}$ in human blood. II. Levels of vitamin $\mathrm{E}$ in the blood of British men and women, 1952-7. Brit. J. Nutr., 14, 281-287.

MacLean, L. D., Perry, J. F., Kelly, W. D., Mosser, G. D., Mannick, A., and Wangensteen, O. H. (1954). Nutrition following subtotal gastrectomy of four types (Billroth I and II, segmental, and tubular resections). Surgery, 35, 705-718.

Majaj, A. S., Dinning, J. S., Azzam, S. A., and Darby, W. J. (1963). Vitamin $E$ responsive megaloblastic anemia in infants with protein-calorie malnutrition. Amer. J. clin. Nutr., 12, 374-379.

Marks, J. (1962). Critical Appraisal of the therapeutic value of $\alpha$-tocopherol. Vitam. u. Horm., 20, 573-598.

Martinek, R. G. (1964). Method for the determnation of vitamin E (total tocopherols) in serum. Clin. Chem., 10, 1078-1086.

Marvin, H. N., and Audu, I. S. (1964). A preliminary study of vitamin $E$ and the anaemia of Kwashiorkor. W. Afr. med. J., 13, 3-8.

Paulson, M., and Harvey, J. C. (1954). Hematological alterations after total gastrectomy. Evolutionary sequences over a decade. $J$. Amer. med. Ass., 156, 1556-1560.

Rose, C. S., and György, P. (1952). Specificity of hemolytic reaction in vitamin E-deficient erythrocytes. Amer. J. Physiol., 168, 414 420.

Sandstead, H. H., Gabr, M. K., Azzam, S., Shuky, A. S., Weiler, R. J., El Din, O. M., Mokhtar, N., Prasad, A. S., El Hifney, A., and Darby, W. J. (1965). Kwashiorkor in Egypt. II. Hematologic aspects (the occurrence of a macrocytic anemia associated with low serum vitamin $E$ and a wide range of serum vitamin $\mathbf{B}_{12}$ levels). Amer. J. clin. Nutr., 17, 27-35.

Shingleton, W. W., Isley, J. K., Floyd, R. D., Sanders, A. P., Baylin, G. T., Postlethwait, R. W., and Ruffin, L. M. (1957). Studies on postgastrectomy steatorrhea using radioactive triolein and oleic acid. Surgery, 42, 12-21.

Tyor, M. P., and Ruffin, J. M. (1958). Effect of pre-feeding on fat on $I_{131}$ triolein absorption in subtotal gastrectomy patients. Proc. Soc. exp. Biol. (N.Y.), 99, 61-64.

Visick, A. H. (1948). Measured radical gastrectomy. Review of 505 operations for peptic ulcer. Lancet, 1, 505-510, 551-555.

Weir, D. G., and Gatenby, P. B. B. (1963). Subacute combined degeneration of the cord after partial gastrectomy. Brit. med. J., 2, 1175-1176. 